\title{
Recurrence After Radical Prostatectomy for Organ-Confined Prostate Cancer
}

\author{
$\begin{array}{lll}\text { J.R. Scheepe } & \text { A. N. Vis } & \text { G. H. Mickisch } \\ & \text { b }\end{array}$ \\ a Department of Urology, University Hospital Erasmus MC, Rotterdam, The Netherlands \\ ${ }^{\text {b}}$ Centrum für Operative Urologie Bremen, Germany
}

Key Words

Prostate cancer - Surgical margins · PSA · Progression . Prognosis

\section{Summary}

Background: Some patients from our radical prostatectomy (RPx) series with organ-confined ( $\mathrm{pT} 2$ ) prostate cancer and negative surgical margins show a PSA (prostate specific antigen) relapse. Aim of the study was to analyze this cohort of patients that otherwise would have been considered to be cured. $\mathbf{P a}$ tients and Methods: Since the introduction of PSA measurement in the follow-up after RPx, 475 pelvic lymph node dissections with subsequent RPx were performed in our department from 1988 to 1997. Of these, 227 were classified as pT2, 34 (15\%) exhibited positive surgical margins, and 4 others were excluded due to an inadequate follow-up. Of the remaining 189 patients (study cohort), 19 (10\%) developed a biochemical progression, defined as a minimum of 2 consecutive PSA measurements $\geq 0.1 \mathrm{ng} / \mathrm{ml}$. Only in one of them a G3 tumor was present Median follow-up was 19.1 months. Results: The Kaplan-Meier analysis of biochemical progression showed that after 1, 2 and 5 years, 95\% (confidence interval (Cl) 91-99\%), 91\% ( $\mathrm{Cl} 86-96 \%$ ) and $77 \%(\mathrm{Cl} 55-89 \%)$ of the patients were free of progression respectively. This means that roughly one fourth of pT2 tumors will become progressive despite negative surgical margins. These 19 patients were subdivided into 4 groups: 1: biopsy-proven local recurrence $(n=2) ; 2$ : suspected local recurrence defined as slowly rising PSA $\leq 2 \mathrm{ng} / \mathrm{ml}$, but negative biopsies ( $\mathrm{n}=$ 12); 3: distant metastasis proven by radiologic imaging $(n=1)$; 4: suspected distant metastasis defined as rapidly rising PSA > $9 \mathrm{ng} / \mathrm{ml}$ without direct radiologic evidence $(\mathrm{n}=4)$. Preoperatively all patients from groups $3+4$ had negative bone scans and $4 / 5$ had preoperative PSA values $<10 \mathrm{ng} / \mathrm{ml}$. In total 7 patients with proven recurrence or with proven metastasis had positive biopsies. Conclusion: A pathological diagnosis of organ-confined prostate cancer ( $\mathrm{pT} 2$ ) and a meticulous analysis of negative surgical margins do not exclude the occurrence of local relapses in 7\% (14/189), and there is evidence for suspect hematogenic spread of PC cells in at least $2 \%(4 / 189)$ of patients.
Schlüsselwörter

Prostatakarzinom - Chirurgischer Absetzungsrand . PSA · Progression · Prognose

\section{Zusammenfassung}

Hintergrund: Einige Patienten, die eine radikale Prostatektomie (RPx) wegen eines organbegrenzten Tumors erhielten, weisen trotz eines negativen Absetzungsrandes ein PSA(Prostata-spezifisches Antigen)-Rezidiv auf. Ziel der Studie war es, diese Gruppe von Patienten näher zu untersuchen, die anderenfalls als geheilt angesehen worden wäre. Patienten und Methoden: Seit der Einführung von PSA-Analysen bei der Nachsorge unserer Patienten nach RPx, wurden von 1988 bis 1997475 pelvine Lymphknotenausräumungen mit nachfolgender RPx durchgeführt. 227 davon wurden als pT2 beurteilt, 34 (15\%) wiesen einen positiven Absetzungsrand auf, und 4 weitere wurden wegen ungenügender Nachsorge von der Analyse ausgeschlossen. Von den übrigen 189 Patienten (Studien-Kohorte) entwickelten $19(10 \%)$ ein biochemisches Rezidiv, definiert als minimal 2 aufeinander folgende PSA-Messungen $\geq 0,1 \mathrm{ng} / \mathrm{ml}$. Nur bei einem Fall wurde ein G3-Tumor nachgewiesen. Die mediane Nachsorgezeit erreichte 19,1 Monate. Ergebnisse: Die KaplanMeier-Analyse für biochemische Progression zeigte, dass nach jeweils einem, 2 und 5 Jahren 95\% (Konfidenz-Intervall (Cl) 91-99\%), 91\% ( $\mathrm{Cl} 86-96 \%$ ), und 77\% (Cl 55-89\%) der Patienten progressionsfrei waren. Dies bedeutet, dass ungefähr ein Viertel der Tumoren im Stadium pT2 trotz negativer Absetzungsränder progressiv werden. Diese 19 Patienten wurden in 4 Gruppen unterteilt: 1: Durch Biopsie nachgewiesenes lokales Rezidiv $(n=2) ; 2$ : Vermutliches Lokalrezidiv definiert als langsam steigender PSA-Wert $\leq 2 \mathrm{ng} / \mathrm{ml}$, aber negative Biopsien $(\mathrm{n}=12) ; 3$ : Durch Röntgendiagnose bewiesene Fernmetastasierung $(n=1)$; 4: vermutliche Fernmetastasierung definiert als schnell steigender PSA-Wert $>9 \mathrm{ng} / \mathrm{ml}$ ohne direkten radiologischen Beweis ( $\mathrm{n}$ $=4$ ). Alle Patienten der Gruppen $3+4$ waren negativ im präoperativen Knochenszintigramm, und $4 / 5$ wiesen präoperative PSAWerte $<10 \mathrm{ng} / \mathrm{ml}$ auf. Insgesamt konnten bei 7 Patienten mit nachgewiesener Metastasierung oder Lokalrezidiv positive Biopsien erhalten werden. Schlussfolgerungen: Die histopathologische Diagnose eines organbegrenzten Tumors (pT2) und eine intensive Analyse von negativen Absetzungsrändern schließt in 7\% (14/189) der Fälle das Auftreten von Lokalrezidiven nicht aus, und es finden sich Hinweise für eine primäre hämatogene Metastasierung des Prostatakarzinoms in zumindest 2\% (4/189) der Fälle.

\begin{tabular}{ll}
\hline KARGER & @ 2003 S. Karger GmbH, Freiburg \\
Fax +497614520714 & Accessible online at: \\
$\begin{array}{l}\text { E-mail Information@Karger.de } \\
\text { www.karger.com }\end{array}$ & www.karger.com/onk
\end{tabular}

Prof. Dr. med. Gerald H. J. Mickisch

Centrum für Operative Urologie Bremen

Robert-Koch-Str. 34a

D-28277 Bremen

Tel. +49 421 8700-300, Fax -309

E-mail gerald.mickisch@coub.de 


\section{Introduction}

It is generally accepted that PSA (prostate specific antigen) is produced nearly exclusively by prostatic epithelial cells [1]. Because the curative intent of radical prostatectomy is to remove all prostatic tissue (normal, benign prostatic hyperplasia, and adenocarcinoma), serum PSA should decline to undetectable concentrations after radical surgery. With the exception of a few and mostly anecdotal reports of local recurrences after radical prostatectomy with undetectable serum PSA concentrations [2], most men with disease recurring after surgery either locally $[3,4]$ or as distant spread $[5,6]$ have detectable serum PSA levels.

Most large series evaluated PSA progression in the context of tumors exhibiting capsular penetration ( $\geq$ pT3), with a positive surgical margin status bearing a negative impact on prognosis [7, 8]. Overall, surgical margin status has been reported to be of equivocal significance $[9,10]$, particularly in organconfined disease [11].

This article focuses on the use of serum PSA after anatomic radical prostatectomy for pathologically localized prostate cancer so as to investigate cancer progression in a group of patients that normally would have been considered to be cured.

\section{Patients and Methods}

From January 1, 1988 to December 31, 1997, 475 bilateral pelvic lymph node dissections with subsequent retropubic radical prostatectomies were performed at the Department of Urology, Erasmus University Hospital, Rotterdam by or under the guidance of a certified urologic surgeon. The date January 1988 was chosen as the initial date because this is when serum PSA concentrations became available for routine clinical use at our institution. Consequently, the minimum observation period for this cohort of patients was 54 months. During this same interval, an additional 52 men were found to have positive lymph nodes at frozen section and as a result did not undergo radical prostatectomy. Patients were aged $43-75$ years with a median of 66 years.

Preoperative tumor staging consisted of digital rectal examination, serum PSA determination and radioisoptope bone scanning with confirmatory imaging studies, if necessary. All tumors were histologically proven by means of ultrasound-guided transrectal sixtant biopsies. In all patients, the tumor was judged clinically to be radically resectable.

The radical prostatectomy specimens were graded histologically according to the Gleason system and categorized as being well (Gleason sums 2-4), moderately (Gleason sums 5-7) or poorly (Gleason sums 8-10) differentiated. The TNM system of 1992 was used for clinical and pathological staging. Frozen sections and subsequent paraffin-embedded sections of all lymph nodes removed during the bilateral pelvic lymph node dissection were examined. Immediately after resection, the pathologist investigated the radical prostatectomy specimens by gross inspection, weighed them, coated the entire external surface with India ink [12] and fixed the specimens in 10\% formalin for 18-24 hours. All paraffin fixed surgical margins including the prostatic base, apex, urethra, bladder neck, capsule, periprostatic soft tissue, seminal vesicles and multiple routine step sections of the prostate, perpendicular to the long axis (apical-basal) were examined histologically. Pathologic stage was determined as organ-confined ( $\leq \mathrm{pT} 2)$, capsular penetration $(\mathrm{pT} 3 \mathrm{a}+\mathrm{b})$ or seminal vesicle involvement $(\mathrm{pT} 3 \mathrm{c})$.

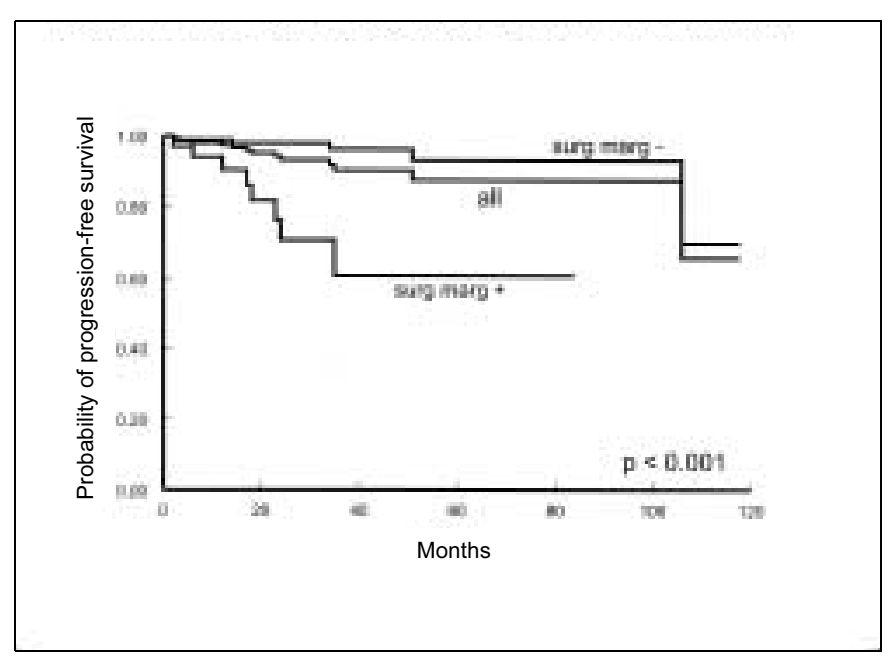

Fig. 1. Prognostic implication of positive surgical margins. Kaplan-Meier estimates on the probability of biochemical progression after curative radical prostatectomy in organ-confined disease $(\mathrm{n}=189)$. Surg marg: surgical margin; -: negative; +: positive; all: all patients.

The surgical margin status was regarded positive when the tumor extended at any given section to the inked surface.

We prospectively entered clinical and pathological data in our follow-up data base. Patients were evaluated quarterly for the first year, biannually for the next year and annually thereafter if there was no evidence of cancer progression. We contact patients who do not comply with this schedule by mail or by telephone. Digital rectal examination and PSA testing was performed at each visit. PSA of $\geq 0.1 \mathrm{ng} / \mathrm{ml}$ at two consecutive measurements was considered evidence of biochemical progression. Radioisoptope bone scanning with confirmatory imaging studies, if necessary, were done in the event of a postoperative PSA elevation. Local recurrence was established by transrectal ultrasound-guided biopsy of the anastomotic region. Progression was defined as elevated postoperative PSA, local recurrence or distant metastasis.

The radical prostatectomy specimens were routinely fixed in $10 \%$ buffered formalin, $\mathrm{pH}=7.4$, embedded in paraffin, freshly cut into $4 \mu \mathrm{m}$ sections and mounted on amino alkylsilane coated glass slides. Hematoxylin and eosin slides were reviewed by a specialized uro-pathologist. The Gleason growth pattern was determined for all tumor sections in the prostate and the tumor was staged according to the 1992 pathological TNM system. Of all specimens 1-3 paraffin tissue blocks representative of the whole tumor were selected. Selection was based on the presence of the poorest grade in the radical prostatectomy specimens, assuming that these growth patterns in the tumor would predict outcome.

\section{Results}

Of our patients 227 (48\%) were classified as stage pT2 (organconfined) of whom 34 (15\%) exhibited positive surgical margins (17 apically, 16 laterally, 1 both). 4 others were excluded due to inadequate follow-up. Of the remaining 189 patients (study cohort; $40 \%$ of total patient population; $83 \%$ of pT2 tumors), 19 (10\%) developed a biochemical progression as a first indication for cancer progression; in some cases a PSArelapse after reaching undetectable levels occurred within the 
first year postoperatively. 7 patients (4\%) had a well, 11 patients $(5 \%)$ a moderately and only 1 patient $(1 \%)$ a poorly differentiated tumor.

The Kaplan-Meier biochemical progression analysis showed that after 1 year 95\% (confidence interval 91-99\%) were free of progression. The same result applied after 2 years to $91 \%$ (confidence interval $86-96 \%$ ), and after 5 years to $77 \%$ (confidence interval 55-89\%) of the study group. This means that overall one fourth of patients with organ-confined prostate cancer will become progressive despite negative surgical margins at radical prostatectomy. Furthermore, we analyzed the prognostic impact of the surgical margin status in the group of organ-confined (pT2) prostate cancer. Figure 1 clearly demonstrates that the probability of biochemical progression after radical prostatectomy in pT2 disease is significantly associated with presence or absence of a putative surgical eradication of prostate cancer cells from the primary tumor site.

Moreover, we subdivided the 19 progressive patients into 4 groups in accordance with the pattern of PSA-relapse over time:

1: biopsy-proven local recurrence ( $\mathrm{n}=2 ; 1 \%$ of study cohort),

2: suspected local recurrence, but negative biopsies $(\mathrm{n}=12$; $6 \%$ of study cohort),

3: radiologic imaging proven distant metastasis $(n=1) ; 1 \%$ of study cohort),

4: suspected distant metastasis, but negative bone scans ( $\mathrm{n}=$ $4 ; 2 \%$ of study cohort).

Patients from groups 1 and 2 showed a slowly rising PSA $\leq 2$ $\mathrm{ng} / \mathrm{ml}$, whereas patients from groups 3 and 4 presented with a rapidly rising PSA $>9 \mathrm{ng} / \mathrm{ml}$. All patients from the latter 2 groups demonstrated negative bone scans preoperatively, and $4 / 5$ had preoperative PSA values $<10 \mathrm{ng} / \mathrm{ml}$. Except for one case who exhibited a micro-metastasis at definitive paraffin section (frozen section negative), all pelvic lymph node dissections revealed no lymphatic spread of prostate cancer. 7 of the 19 progressive patients had positive biopsies or were highly suspected for distant metastasis ( $4 \%$ of study cohort).

Hence, a pathological diagnosis of organ-confined prostate cancer and a meticulous analysis of negative surgical margins does not exclude the occurrence of a local relapse in $7 \%$ $(14 / 189)$, and there is evidence for a suspect primary hematogenic spread of prostate cancer in at least $2 \%(4 / 189)$ of patients.

\section{Discussion}

Radical prostatectomy is an effective therapy for prostate cancer, especially when the tumor is organ-confined at final pathological analysis $[4,7,8]$. However, it is apparent that $5-23 \%$ of those patients will experience recurrences even when lesions are confined pathologically to the prostate and surgical margins are reported to be negative. Thus, the natural history of prostate cancer can be variable following definitive therapy. Although a 10- to 15 -year follow-up is necessary to definitively quantify clinical progression rates, the availability of serum PSA as a marker of persistent or recurrent disease has telescoped the time to tumor progression, thus allowing for interim evaluation of disease status in patients followed for shorter intervals like in our study.

An increase in serum PSA after the patient had achieved female levels may precede clinical evidence of local recurrence or distant metastasis by several months or years, although the clinical relevance of such postoperative elevations is not entirely clear [9]. Nonetheless, PSA is presently the most sensitive and specific marker available to monitor patients after radical prostatectomy. The half-life of serum PSA is 3.15 days [1]. While the technology is still evolving and there remains some controversy [1], an undetectable serum PSA concentration is less than $0.1 \mathrm{ng} / \mathrm{ml}$. This would predict that even a serum PSA concentration of $50 \mathrm{ng} / \mathrm{ml}$ should become undetectable 30 days after surgical removal of the prostate. Several studies have investigated the significance of measurable serum PSA within the first year after surgery. Stein et al. [3] reported that $50 \%$ of 14 men who had detectable serum PSA concentrations within one year after prostatectomy subsequently developed either local recurrence or distant disease. Lange et al. [13] described $100 \%$ (16/16) progression, and in the Catalona series [9] a 51\% (17/33) progression rate became obvious for similar groups of patients. The largest cohort [10] demonstrated a $60 \%$ (23/38) progression rate for men who had detectable serum PSA within the first postoperative year. Both the 5- and the 10-year actuarial progression-free probabilities for those patients with PSA recurrences within the first year are significantly lower than those for men whose disease recurred after the first year [10].

Because the majority of patients in our series experienced detectable PSA concentrations within the initial postoperative year, there is ample evidence that the biochemical progression analyzed in this study will eventually translate into clinical recurrences even in this group of patients with organ-confined prostate cancer with negative surgical margins that otherwise would have been considered to be cured. Indeed, only the introduction of PSA in the follow-up after radical prostatectomy has made it possible to detect this new subgroup of prostate cancer patients.

Failure of radical prostatectomy for apparent pathologically organ-confined tumor is not easily understood. PSA values that remain persistently elevated despite organ-confined disease may represent subclinical hematogeneous metastases or incomplete resection of the primary tumor with pathological tissue sampling error. However, PSA elevations after initial return to undetectable levels like in our series are even more difficult to explain. Again, an erroneous pathological classification involving either cancer penetrating the prostate capsule (pT3) and/or an anatomically incorrect dissection plane (unrevealed positive surgical margins), leaving minute amounts of prostatic tissues (benign or cancerous) behind, with subse- 
quent progression may account for the interesting new cohort of patients. In addition, inadequate PSA testing should be ruled out, but there remains evidence for hematogenic spread of prostate cancer cells without involvement of the loco-regional lymphatic drainage in at least $2 \%$ of our patients (4/189). Further studies including descriptive determinations of biological aggressiveness such as tumor grade, DNA ploidy, microvascular tumor invasion, and functional molecular markers of tumor angiogenesis, tumor adhesion, and drug resistance factors [12] are required to thoroughly investigate the patterns of failure after putatively curative radical prostatectomy.

\section{References}

1 Oesterling JE: Prostate specific antigen: A critical assessment of the most useful tumor marker for adenocarcinoma of the prostate. J Urol 1991;145: 907-923.

2 Takayama T, Krieger JN, True LD: Recurrent prostate cancer despite undetectable prostate specific antigen. J Urol 1992;148:1541-1542.

3 Stein A, Dekernion JB, Smith RB, Dorey F, Patel H: Prostate specific antigen levels after radical prostatectomy in patients with organ-confined and locally extensive prostate cancer. J UroI 1992;147: 942-946.

4 Zincke H, Oesterling JE, Glute ML, Bergstralh EJ, Myers RP, Barrett DM: Long-term (15 years) results after radical prostatectomy for clinically localized (stage T2c or lower) prostate cancer. J Urol 1994;152:1850-1857.

5 Ohori M, Goad JR, Wheeler TM, Eastham JA, Thompson TC, Scardino PT: Can radical prostatectomy alter the progression of poorly differentiated prostate cancer? J Urol 1994;152:1843-1849.

6 Paulson DF: Impact of radical prostatectomy in the management of clinically localized disease. J Urol 1994;152:1826-1830.

7 Mickisch GH, Kranse R, Verkerk A, Hoedemaker R, Schroeder F: Biochemical progression after surgically radical resection for pT2 prostate cancer. J Urol 1998;159:217.

8 Partin AW, Pound CR, Clemens JQ, Epstein JI, Walsh PC: Serum PSA after anatomic radical prostatectomy. The John Hopkins experience after 10 years. Urol Clin North Am 1993;20:713-725.

9 Catalona WJ, Smith DS: 5-year tumor recurrence rates after anatomical radical retropubic prostatectomy for prostate cancer. J Urol 1994;152:1837- 1842

10 Epstein JI, Partin AW, Sauvageot J, Walsh PC: Prediction of progression following radical prostatectomy. A multivariate analysis of 721 men with long-term follow-up. Am J Surg Pathol 1996;20:286-292.

11 Lerner SE, Blute ML, Bergstralh EJ, Bostwick DG, EickhoIt JT, Zincke H: Analysis of risk factors for progression in patients with pathologically confined prostate cancers after radical retropubic prostatectomy. J Urol 1996;156:137-143.

12 van Brussel JP, van Steenbrugge GJ, van Krimpen C, Bogdanowicz JFAT, van der Kwast TH, Schroeder FH, Mickisch GHJ: Expression of multidrug resistance related proteins and proliferative activity is increased in advanced clinical prostate cancer. J Urol 2001;165:130-135.

13 Lange PH, Ercole CJ, Lightner DJ, Fraley EE, Vesella R: The value of serum prostate specific antigen determinations before and after radical prostatectomy. J Urol 1989;141:873-879.

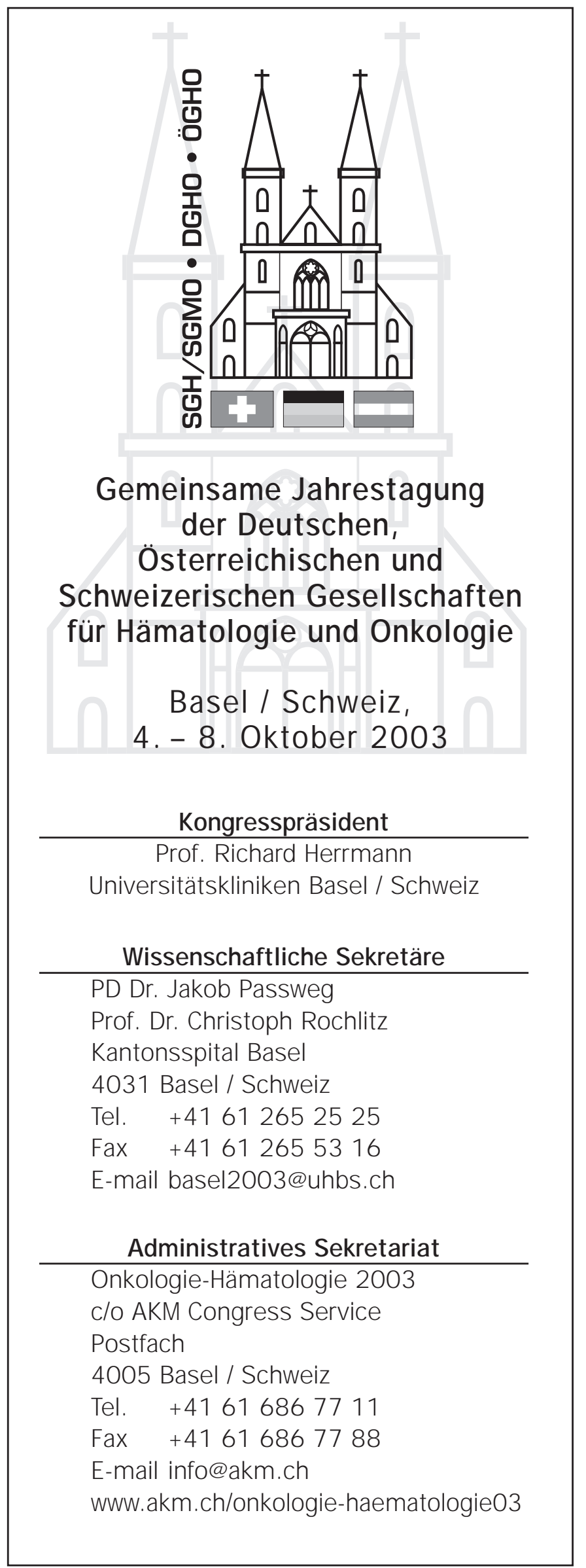

PD Dr. Jakob Passweg

Prof. Dr. Christoph Rochlitz

Tel. $\quad$ +41612652525

Fax +41612655316

E-mail basel2003@uhbs.ch

Administratives Sekretariat

Onkologie-Hämatologie 2003

c/o AKM Congress Service

Postfach

4005 Basel / Schweiz

Tel. $\quad$ +41616867711

Fax $\quad+41616867788$

E-mail info@akm.ch

uww.akm.ch/onkologie-haematologie03 